\title{
EL RETABLO SACRAMENTAL DE LA PARROQUIA DE SANTIAGO DE ÉCIJA
}

\section{THE BLESSED SACRAMENT ALTARPICE OF THE PARISH CHURCH OF SANTIAGO OF ÉCIJA}

\author{
Gerardo García LeÓN \\ Consejería de Cultura. Junta de Andalucía. España \\ gerardo.garcia@juntadeandalucia.es
}

\begin{abstract}
Se aportan documentos fundamentales sobre la historia de uno de los principales retablos del siglo XVI que existen en Écija. Desde ahora podemos conocer la identidad de sus autores, su fecha de realización, así como los diversos avatares y transformaciones sufridas por esta obra, desde 1533 hasta nuestros días.

Palabras clave: Gótico, Renacimiento, retablo, escultura, pintura, Écija, Bartolomé de Ortega, Nicolás de León, Juan Sánchez, Andrés Morín, Pedro de Campaña, Francisco Javier Díaz de Acevedo.

Important documents about the history of one of the main altarpieces of the 16th century in Écija are provided. Now we know the identity of those who built it, when it dates from as well as the range of the historical changes it has undergone since 1533.

Keywords: Ghotic, Renaissance, altarpiece, sculpture, painting, Écija, Bartolomé de Ortega, Nicolás de León, Juan Sánchez, Andrés Morín, Pedro de Campaña, Francisco Javier Díaz de Acevedo.
\end{abstract}

En ocasiones, la investigación en los archivos depara gratas sorpresas que pueden ayudar a paliar, si bien parcialmente, la irremediable pérdida o ausencia de importantes series documentales que se consideran fuentes básicas para el conocimiento de la historia del arte. Una de estas series archivísticas son las llamadas cuentas de fábrica, documento fundamental de la contabilidad parroquial, que permitían el control y la supervisión durante las periódicas visitas al templo que realizaban los representantes de la autoridad arzobispal. En estas cuentas los mayordomos de fábrica consignaban anualmente todas las partidas de ingresos y gastos que hacían posible la existencia de la institución parroquial y de ellas se extraen valiosas informaciones para establecer la filiación artística del patrimonio que atesoran muchas de nuestras iglesias. 
El estudio de un pleito entablado en 1612, a raíz de la propiedad, el patronazgo y derecho de uso de la capilla sacramental de la parroquia de Santiago de Écija nos ha transmitido -entre otros muchos e interesantes documentos- un extracto de la contabilidad de esa iglesia que se hallaba anotada en tres libros de cuentas de fábrica del siglo XVI, hoy perdidos, que contenían todos los datos relativos a la construcción del retablo mayor de esta capilla, y que demuestran que fue llevado a cabo entre 1533 y 1552.

La iglesia de Santiago es uno de los seis templos parroquiales con los que contó Écija desde la Edad Media. Su origen aparece vinculado a cierta leyenda de carácter bélico, según la cual, la ciudad logró superar un ataque de las tropas islámicas gracias a la milagrosa intervención del santo. Aunque la historiografía local ha venido estableciendo su fundación en el siglo XV, nuevos testimonios documentales hallados en los archivos ecijanos prueban que su origen es mucho más antiguo, pues consta en ellos que la parroquia ya existía en 1398 y que, entre sus clérigos, había un cura beneficiado llamado Juan Fernández que, por aquel año, formaba parte de la Universidad de Beneficiados de Écija ${ }^{1}$.

El actual templo parroquial de Santiago fue construido entre los últimos años del siglo XV y los comienzos de la centuria siguiente, posee planta de cruz latina, con tres naves separadas por arcos apuntados sobre pilares fasciculados. En armonía con el estilo gótico de su fábrica, muestra triple cabecera con bóvedas de nervaduras sobre pilares y contrafuertes. La techumbre de las naves constituye un buen ejemplo de la rica carpintería mudéjar ecijana, destacando la notable armadura policromada de la nave central. La iglesia contiene algunos de los retablos más importantes que se conservan en Écija: el retablo mayor, muy vinculado con los artífices que llevaron a cabo la magna empresa del retablo mayor de la catedral de Sevilla, y el retablo de la capilla sacramental ${ }^{2}$, sobre el que ahora avanzamos todos los da-

${ }^{1}$ APSME. (Archivo Parroquial de Santa María de Écija), legajo 273, ff. 44 r-v. Así se demuestra en la escritura de donación de una haza de tierra calma a la Universidad de Beneficiados de Écija, realizada por los hermanos Alfón y Catalina Martínez, el día 17 de septiembre de 1398.

${ }^{2}$ HERNÁNDEZ DÍAZ, José: Arte y artistas del renacimiento en Sevilla. Documentos para la Historia del Arte en Andalucía, T. VI, Sevilla, 1933, pp. 91-92. HERNÁNDEZ DÍAZ, José, SANCHO CORBACHO, Antonio, COLLANTES de TERÁN, Francisco: Catálogo Arqueológico y Artístico de la Provincia de Sevilla, t. IV, Sevilla, 1950, p. 136. ANGULO ÍÑIGUEZ, Diego: La Pintura del Renacimiento. Ars Hispaniae, v. XII. Madrid, 1954, p. 209. SERRERA, Juan Miguel: "Pedro de Campaña: obra dispersa". Archivo Español de Arte, n 245, 1989, pp. 8-25. VV.AA. Historia del Arte en Andalucía. El arte del renacimiento, vol. V, Sevilla, 1989, pp. 260-261 y 268. MORALES, Alfredo, SANZ, Mª Jesús, SERRERA, Juan Miguel, VALDIVIESO, Enrique: Guía artística de Sevilla y su provincia, vol. II, Sevilla, 2004, pp. 405-406. VALDIVIESO, Enrique: Pedro de Campaña. Sevilla, 2008, pp. 132.136. HERRERA GARCÍA, Francisco: "Los orígenes de una afortunada 
tos relativos a su construcción ${ }^{3}$. Según las cuentas parroquiales descubiertas, este retablo fue llevado a cabo entre 1533 y 1552, tuvo un coste total de 12.408 reales y, en su realización, intervinieron los siguientes artistas: el entallador Bartolomé de Ortega (1533-1542); el escultor Nicolás de León (1539-1542); los pintores y doradores Juan Sánchez (1542-1544) y Andrés Morín (1542-1552); y el pintor Pedro de Campaña $(1550)^{4}$.

\section{EL PLEITO POR LA CAPILLA DEL SAGRARIO}

Como se desprende del estudio de la documentación conservada, a comienzos del siglo XVII la capilla sacramental de Santiago pertenecía a la familia de los Mendoza, miembros de la oligarquía ecijana y descendientes de Juan Rodríguez de Mendoza, caballero del rey5. Pero, además de hallarse bajo su suelo el panteón funerario de este clan familiar, al mismo tiempo esta capilla también era utilizada por la hermandad del Santísimo Sacramento. La convivencia entre los patronos de la capilla, la fábrica parroquial y la cofradía, no siempre fue armoniosa, como pone de manifiesto el complejo pleito que se inició en 1612 y que resumiremos a continuación.

Aunque la regla de la hermandad del Santísimo Sacramento de la parroquia de Santiago fue aprobada por el Arzobispado de Sevilla en 1590, está demostrado que su creación databa de 1543, gracias a la bula fundacional concedida en ese año por el papa Paulo III ${ }^{6}$. Probablemente, desde sus momentos iniciales, y quizá favorecida por la presencia entre sus hermanos de muchos clérigos de la misma parroquia, la cofradía quedó establecida en la capilla colateral derecha, por ser el lugar donde tradicionalmente se ubicaba el sagrario. A causa de un antiguo pleito, que no se conserva en la actualidad, sabemos que la capilla pertenecía oficialmente a la familia Mendoza desde 1588, gracias a una sentencia dictada por Íñigo de Leciñana, provisor del Arzobispado de Sevilla, que declaraba a Alonso de Mendoza

creación artística. El retablo gótico en Sevilla”, El retablo sevillano. Desde sus orígenes a la actualidad. Sevilla, 2009, pp. 60-61.

${ }^{3}$ El documento que ha servido de origen a este trabajo aparece transcrito en toda su extensión en la obra: GARCÍA LEÓN, Gerardo, MARTÍN OJEDA, Marina: Documentos para la Historia del Arte en Écija. Siglos XVI-XVII (en prensa).

4 AGAS. (Archivo General del Arzobispado de Sevilla). Justicia, legajo 09886, expediente 1, ff. 70r-79r.

5 FERNÁNDEZ DE GRAJERA, Alonso: Historia de la çiudad de Éçixa. Sevilla, 1995, p. 202. Una de las principales calles del arrabal y collación de Santiago era conocida desde época medieval con el nombre de Mendoza, denominación que aún se conserva en la actualidad.

${ }^{6}$ MARTÍN OJEDA, Marina: "Hermandad y cofradía del Santísimo Sacramento de la parroquia de Santiago (Écija). 1590", CIX Reglas de hermandades y cofradías andaluzas. Siglos XIV, XV y XVI. Huelva, 2002, Regla LXIV. 
Marroquí como patrono y legítimo poseedor de la capilla del sagrario de Santiago, con facultad para utilizar el enterramiento que existía bajo la misma, para él y sus descendientes.

En 1612 Francisco de Biedma y Mendoza, por entonces titular de los derechos sobre la capilla, decidió venderla por 2.000 reales al doctor Francisco de Baeza, canónigo de la catedral de Sevilla ${ }^{7}$. Al mismo tiempo, ordenó acometer unas obras de reforma en la misma, durante las que se retiraron los escudos e insignias de la hermandad del Santísimo Sacramento, así como cierta inscripción que proclamaba el vínculo de la cofradía con dicho lugar. Como es lógico, esto suscitó la inmediata reacción de la hermandad, que en 1613 denunció el atropello ante el Arzobispado $^{8}$. La congregación alegaba que se le estaba arrebatando el uso de una capilla que siempre consideraron como suya, y que por ello la habían "dotado y ornado, dándole lánparas de plata y azeyte para ellas, rejas de hierro doradas y por armas suyas tiene pintada una custodia del Santísimo Sacramento, y en ella tiene el herario donde se guardan las bullas y las otras cosas pertençientes a dicha cofradia"."

Plenamente enzarzados en el pleito patrono y hermandad y, vistas las posturas irreconciliables de ambas partes, el procurador del Arzobispado tomó cartas en el asunto y emitió un informe donde exponía la importancia y seriedad de este litigio, pues se estaba tratando de una capilla muy relevante para el templo, en la que existía un valioso retablo y otros diversos adornos. En su alegato, manifestaba que la capilla había sido ilegalmente adjudicada a la familia Mendoza en la sentencia de 1588 , ante la pasividad de un mayordomo de fábrica poco cuidadoso con los intereses de la iglesia, y "ayudado del vicario que entonces era de la dicha parrochial, que era íntimo amigo suyo". También expresaba que, en este tema, se debían "usar de los remedios ordinarios y extraordinarios que el derecho le concede contra la dicha sentencia, atento que éste es un negocio gravísimo y que el derecho que se pretende, y de que se trata, es de más de veinte mil ducados". Para finalizar, el procurador solicitaba al Arzobispo que lo nombrase defensor de la fábrica parroquial de Santiago, "respecto de que son personas poderosas las con quien se sigue [el pleito]"10.

Obtenida esta representación, el procurador argumentó que la sentencia de 1588 carecía de validez, lamentó que entonces nadie apelara a favor de la iglesia de Santiago y afirmó que la capilla pertenecía, en realidad, a la fábrica parroquial, por ser ésta "la fundadora y dotadora de la citada capilla... (como demuestran) los libros de la visita por donde consta que la dicha fábrica, no solamente fue la fundadora

7 AGAS., legajo 09886, expediente 1, ff. 66r-69r.

8 Ibídem, ff. 1r-2v.

${ }^{9}$ Ibíd.

${ }^{10}$ Ibid., ff. 32r-33r. En su incesante cruce de solicitudes y peticiones, el patrono de la capilla denunció que la hermandad estaba financiando el costoso pleito emprendido con las limosnas de los fieles y devotos del Santísimo Sacramento, lo cual constituía una grave acusación. 
y dotadora, mas que desde el año de treynta y nueve, a esta parte, á gastado en reedificios y reparos mil y docientos y veinte y un ducados"11.

En efecto, y como mencionábamos anteriormente, las cuentas de fábrica de la parroquia de Santiago fueron presentadas como prueba fundamental y confirmaron que el retablo mayor de la capilla sacramental había sido llevado a cabo entre 1533 y 1552, costeando todos los gastos íntegramente la fábrica parroquial. No obstante, Francisco de Biedma Mendoza perseveró en su pretensión y alegó que su familia poseía la capilla mucho antes de que se instalara allí el sagrario de la parroquia. De hecho, es muy probable que entre los Mendoza y la fábrica de Santiago hubiera existido, tiempo atrás, algún tipo de acuerdo de patrocinio y colaboración, que habría resultado decisivo a la hora de dictar la sentencia adjudicataria de 1588 . En este sentido, debe mencionarse que el historiador local Alonso Fernández de Grajera, al glosar la sucesión de los miembros del linaje de los Mendoza, menciona que "Mayor de Mendoza casó con Alonso de Cárdenas, i hizieron la capilla de Santiago" $"$.

Tras una continua sucesión de diligencias, testimonios, interrogatorios a numerosos testigos, autos y sentencias judiciales, el pleito fue apelado ante el nuncio apostólico. Por este motivo, en noviembre de 1614 el provisor del Arzobispado designó al presbítero Alonso Parra, perteneciente a la clerecía de Santiago, para que viajara a Madrid a continuar el pleito, asignándole una ayuda de costa de 1.000 reales. Al referirse a la capilla sacramental de Santiago, el informe de la visita pastoral de 1618 resume los hechos muy acertadamente: "En esta capilla está fundada la cofradía de Santísimo Sacramento y tiene en ella quatro lámparas de plata. Por los libros de la fábrica más antiguos que se an podido hallar, y por los quadernos, consta que esta capilla es de la iglesia y que, a su costa, la á reparado y enluzido, que todo lo que tiene, frontales y adereços de los altares, los á hecho a su costa la fábrica, y las rexas y lámparas, la cofradía. Un particular tenía en esta capilla su sepultura. Vendiola a un hombre rico que vino de Castilla a vivir a esta ciudad y en la escritura dice que le vende el entierro y capilla, y lo anexo a ella, sin tener más de el uso de una sepultura. Quiso el comprador entrarse de hecho y echar fuera la cofradía. Salieron los clérigos al negocio. An defendidolo a su costa. Entiendo que desto se á dado cuanta a vuestra señoría ilustrísima. Yo dexo ordenado que saquen testimonio de las razones que tocan a esta capilla en los mandatos desta visita para que se defienda esta capilla y acudan a dar cuenta a vuestra señoría ilustrísima, porque é entendido que, con el favor que tiene en Sevilla con el doctor Balza el comprador desta sepultura, ovieren escurecer la justicia

${ }^{11}$ Ibíd., ff. 63r-64r. Estos 1.221 ducados, equivalentes a 13.431 reales, difieren notablemente de los 12.408 reales que suman las partidas de gastos que aparecen en las cuentas transcritas.

${ }^{12}$ FERNÁNDEZ DE GRAJERA, Alonso: Historia de la çiudad de Éçixa,... op. cit.., p. 203. 
$y$ derecho de la fábrica y que pierda la capilla más ilustre que ay en el arçobispado. Y que tiene de costa el famoso retablo y rexas más de seis mil ducados"13.

La resolución del pleito se logró en 1619 gracias a una sentencia del nuncio, dictada en Madrid, por la que se ordenó mantener los derechos de la familia Mendoza en la persona del litigante Francisco de Biedma Mendoza. No obstante, dicha sentencia también reconocía el derecho de la hermandad del Santísimo Sacramento a celebrar sus cabildos y cultos en la capilla, y a tener en ella su archivo y todos sus enseres. La decisión de la fábrica parroquial de apelar, esta vez al tribunal de la Rota, en la ciudad de Roma, lo que supondría nuevos y cuantiosos gastos, así como la prolongación indefinida del pleito, favoreció que al final se llegara a un acuerdo de compromiso entre todas las partes. El documento de concordia entre el patrono, la cofradía y la fábrica parroquial fue suscrito en Écija el día 5 de noviembre de 1619, y en él se asumieron todos los apartados de la sentencia anterior. Además, se hizo constar que el patrono indemnizaba a la fábrica con 4.950 reales, por los gastos ocasionados en el pleito. Esta cantidad fue abonada por el licenciado Melchor Martínez de Ojacastro y Ozaldúa, vecino de Écija y notario del Santo Oficio, a quien Francisco de Biedma había traspasado todos sus derechos sobre la capilla en $1616^{14}$.

\section{LA CONSTRUCCIÓN DEL RETABLO DEL SAGRARIO}

La realización de un retablo para exornar la capilla sacramental de la iglesia de Santiago fue una iniciativa patrocinada y costeada íntegramente por la fábrica parroquial de Santiago, en cumplimiento de las instrucciones del provisor y vicario general del Arzobispado de Sevilla. Estas disposiciones, llamadas "mandatos de visitas", quedaban anotadas en las actas de las visitas pastorales que periódicamente inspeccionaban el estado de conservación y ornato del templo, su contabilidad parroquial, así como la buena conducta y el celo profesional que los eclesiásticos demostraban durante el desempeño de su labor evangélica.

Según las cuentas de fábrica de 1533, en lo que se refiere a la capilla del sagrario, en ese año "se encaló el arco e se acavó, y se començó el sagrario"15. En consecuencia, debemos considerar ese año como el inicio de los trabajos de construcción de una de las obras cumbres de la retablística del siglo XVI conservadas en Écija. $\mathrm{Al}$ año siguiente, las cuentas consignan el primer pago realizado al maestro entallador Bartolomé de Ortega "para el retablo del sagrario que se haçe”, y concluyen con un mandato claro y expreso: "que se acave el sagrario de su talla y dorado"16.

13 AGAS., legajo 04503. El doctor Francisco Balza había sido secretario del cardenal de Sevilla y en 1618 era canónigo penitenciario de la catedral hispalense.

14 APNE. (Archivo de Protocolos Notariales de Écija), legajo 1297, ff. 2.893r-2.905v.

15 AGAS., legajo 09886, expediente 1, f. 70r.

${ }^{16}$ Ibídem., f. 70v. 
También especifican que los altares de la capilla debían decorarse con azulejos y que el recinto debería quedar cerrado mediante una reja de hierro, tal y como estaba el sagrario de la parroquia mayor de Santa Cruz.

Los pagos en metálico a Bartolomé de Ortega se suceden de forma ininterrumpida desde 1534 hasta 1542 . En 1539 aparece el primer pago a Nicolás de León, "ymaginario..., por las imágenes que para el sagrario haze"17. En noviembre de ese mismo año, y mientras continuaban los trabajos del retablo, fue preciso reparar la cubierta exterior de la capilla, reponiendo la armadura de madera del tejado y la mayor parte de sus tejas, para garantizar la seguridad de la costosa obra que se llevaba a cabo, y que quedaría instalada bajo la bóveda gótica del sagrario ${ }^{18}$.

En 1540 el visitador del Arzobispado evaluó el trabajo realizado hasta ese momento por Bartolomé de Ortega en 3.823 reales, y ordenó que se le continuara pagando hasta la conclusión de su tarea. Al año siguiente el visitador Diego de Loaisa consideró que la obra se hallaba muy retrasada y dispuso que el dinero destinado a la ejecución de un terno bordado para la parroquia se dedicara a terminar el retablo del sagrario, amenazando al mayordomo con la pérdida de su propio salario, si no cumplía su mandato ${ }^{19}$.

En 1542 Bartolomé de Ortega y Nicolás de León ya habían terminado sus trabajos para el retablo. Ese mismo año comenzó la pintura y dorado de la obra, que fue encomendada a los pintores Juan Sánchez y Andrés Morín. El primero de estos pintores sólo trabajó dos años en el retablo; por eso fue Morín quien acaparó la mayor parte de las tareas de policromado del retablo, pues se detectan pagos continuados a este artífice entre 1542 y 1552. Los problemas económicos que acuciaban a la fábrica parroquial de Santiago provocaron que en 1550 hubiera que recurrir al pago en especie, para poder continuar la pintura y dorado. En agosto de ese año se entregaron a Andrés Morín, "porque dorava el sagrario para esta yglesia", cien fanegas de trigo (valoradas en 464 reales), como pago a cuenta de su labor artística ${ }^{20}$. Por esos mismos días se abonaron 440 reales a Pedro de Campaña en una única partida: "Yten en diez e nueve días deste mes pagó a Pedro de Canpania, pintor, quinze mil maravedís porque pintó el retablo para el sagrario de esta yglesia"21.

Los últimos pagos documentados a Andrés Morín fueron abonados en diciembre de 1551. Como entre los mandatos de la visita pastoral efectuada en septiembre de 1552 se indica que aún restaba por pagar una parte del dorado, creemos que la finalización del retablo pudo producirse en ese mismo año, o tal vez a finales del anterior. En visitas posteriores se constató que había existido una demasía en el coste

${ }^{17}$ Ibid., f. $71 \mathrm{v}$.

18 Ibíd. Estas cuentas nos informan que, en 1539, un maestro albañil o de carpintero cobraba al día un salario de 2,5 reales y el peón 1,5 reales.

19 Ibid., f. 74r.

${ }^{20}$ Ibid., f. 76r.

${ }^{21}$ Ibid. 
de la pintura y dorado del retablo, y que Andrés Morín había cobrado 1.140 reales indebidamente. Ante la evidencia que mostraban las cuentas, Morín se obligó en 1557 a devolver esta cantidad, distribuida en diversos plazos durante seis años ${ }^{22}$. Al parecer, en 1561 Andrés Morín no estaba cumpliendo su compromiso, por lo que el visitador ordenó al mayordomo de fábrica de Santiago que apremiase el cobro de la deuda "para que a la visitaçión venidera esté averiguado, so pena que se le cargarán" 23.

Según todos los pagos que aparecen registrados en las cuentas parroquiales, y una vez deducida la demasía detectada en la partida del dorado, el retablo costó a la fábrica un total de 12.408 reales, cifra muy alejada de los 13.431 reales mencionados en el pleito. La justificación para explicar este desfase quizá podamos hallarla en el motivo que expondremos más adelante. En resumen, Bartolomé de Ortega, entallador, cobró 6.570 reales (1534-1542). Nicolás de León, escultor, cobró 882 reales (1539-1542). Juan Sánchez, pintor y dorador, cobró 882 reales (1542-1544). Andrés Morín, pintor y dorador, cobró 3.634 reales (1542-1552). Y, por último, el pintor Pedro de Campaña cobró 441 reales en 1550.

El retablo concluido en 1552 se convirtió, a partir de entonces, en el adorno principal de la capilla sacramental de la parroquia. En 1569, la fábrica contrató al herrero Hernán Martín para que construyera una reja para la capilla del sagrario "que sea torçida, con coraçones, como está hecha en el sagrario de la yglesia de Santa María"24. Esta reja perduró poco tiempo, pues en 1593 fue refundida y sustituida por las que ese año se encargaron al cerrajero Juan Jiménez ${ }^{25}$, esta vez por cuenta de la cofradía del Santísimo Sacramento. El notable esfuerzo económico que supuso la realización del retablo sacramental justifica sobradamente el empeño del Arzobispado por hacer valer sus derechos en el pleito de 1612, tras el cual quedó demostrada la propiedad del retablo y de todo el recinto de la capilla sacramental, frente a las pretensiones de Francisco de Biedma.

\section{LA REFORMA DEL RETABLO DEL SAGRARIO}

Son diversas las actuaciones llevadas a cabo con posterioridad en esta capilla sacramental, que han modificado su disposición inicial y que han determinado el aspecto que hoy presenta. En primer lugar, debemos citar las obras de construcción

${ }^{22}$ HERNÁNDEZ DÍAZ, José: Arte y artistas del Renacimiento en Sevilla...., op. cit., pp. 91-92.

${ }^{23}$ AGAS., legajo 09886, expediente 1, f. 78v.

${ }^{24}$ GARCÍA LEÓN, Gerardo, MARTÍN OJEDA, Marina: Documentos para la Historia del Arte en Écija..., op. cit.

${ }^{25}$ HERNÁNDEZ DÍAZ, José, SANCHO CORBACHO, Antonio, COLLANTES DE TERÁN, Francisco: Catálogo Arqueológico..., op. cit., p. 137. MATA TORRES, Josefa: "Rejas del siglo XVI en la iglesia de Santiago de Écija", Actas del Congreso de Historia "Écija en la Edad Media y Renacimiento", Sevilla, 1993, pp. 477-490. 
de un camarín para el sagrario comulgatorio, costeado por la fábrica parroquial en 1693, y que no ha perdurado hasta nuestros días ${ }^{26}$. Aunque no ha podido ser establecida su ubicación exacta, los informes aportados por los visitadores del Arzobispado nos relatan que se hallaba en un lugar principal de la capilla y que tenía dos altares a los lados. Gracias a los gastos originados durante su construcción, sabemos que se trataba de un camarín cubierto con bóveda semiesférica de yeserías, que podía cerrarse con puertas de madera abatibles y que poseía remates con jarras de azucenas. Su interior, iluminado con ventanales, se hallaba policromado y decorado con figuras de serafines, que fueron llevadas a cabo por el maestro pintor Francisco de Morales ${ }^{27}$. Hasta ahora, toda la bibliografía existente sobre el retablo sacramental de Santiago mencionaba esta intervención como el momento a partir del cual quedó instalado en el retablo del sagrario la imagen del Cristo de la Expiración, desplazando el relieve original de la Santa Cena. Como veremos a continuación, en realidad dicha sustitución no se produjo hasta el año 1792.

Como ha quedado de manifiesto en la restauración llevada a cabo en el retablo durante el año 2007, han sido múltiples los retoques, repintes y alteraciones sufridas por la obra en varios puntos de su estructura y policromía. En concreto, en el siglo XVIII se han podido documentar algunas de estas intervenciones, como ciertas obras de albañilería efectuadas en el banco del retablo, bajo el recuadro de Nuestra Señora de la Antigua. Además, en 1701 se pagaron al pintor Lucas de Vilches "quarenta y dos reales de vellón en retocar a señor San Juan en la tina"28.

El importante crecimiento demográfico experimentado por la ciudad de Écija durante los siglos XVII y XVIII hizo que muchas de sus parroquias medievales quedaran pequeñas o resultaran insuficientes para acoger a todos sus feligreses, especialmente durante las grandes celebraciones religiosas que tenían lugar en los diferentes momentos litúrgicos del año. En la mayoría de los casos se optó por la construcción de nuevas capillas y espacios sagrados, que aportaban otros ámbitos para la religiosidad. Cuando las posibilidades económicas de las fábricas parroquiales lo permitían, el problema se resolvió añadiendo naves paralelas a las ya existentes (Santa María llegó a tener cinco naves) o demoliendo la fachada y prolongando la longitud de las naves (Santa Cruz).

Para el caso de Santiago, la solución fue comprar una casa contigua a la parroquia, al objeto de disponer de un solar sobre el que poder construir nuevas dependencias. Así fue dispuesto en los mandatos de la visita de 1755, "mediante a que la capilla del sagrario comulgatorio de esta yglesia es sumamente pequeña y no correspondiente a la multitud de fieles que la frecuentan, y que también careze de capilla de

${ }^{26}$ HERNÁNDEZ DÍAZ, José, SANCHO CORBACHO, Antonio, COLLANTES DE TERÁN, Francisco: Catálogo Arqueológico..., op. cit., p. 294.

${ }^{27}$ APSME., libro 441, ff. 64-72.

${ }_{28}$ APSME., libro 442, s.f. 
baptisterio y archivo"'29 Según declaraba en 1761 uno de los curas de la parroquia, la collación de Santiago se componía en ese año de 1.099 casas, en las que vivían en torno a 11.000 personas $^{30}$. En consecuencia, una capilla sacramental que ni siquiera llegaba a los cuarenta metros cuadrados de extensión resultaba demasiado estrecha e incómoda para cumplir su función. Por sus características y configuración, era imposible ampliar esta capilla sin modificar sustancialmente la estructura gótica del templo. La solución pasaba por construir un nuevo recinto sacramental, separado de la antigua iglesia, pero conectado a su nave del Evangelio a través de la capilla de las Ánimas, como una dependencia más de la misma. Para este fin se compró en 1756 la mencionada casa contigua, que tuvo de coste para la fábrica 6.808 reales $^{31}$.

$\mathrm{Si}$ a los factores demográficos ya mencionados unimos los efectos devastadores del terremoto de 1755 , así como el periodo de bonanza económica que se vivía, podremos comprender que en el último tercio del siglo XVIII se llevaran a cabo en la parroquia de Santiago importantes obras que ampliaron el recinto y modificaron sustancialmente el aspecto del templo. En este periodo se construyeron una nueva sacristía, el coro con su órgano, el vestuario, la capilla bautismal, el archivo, una gran capilla sacramental, la torre y un patio porticado que servía de ingreso a la iglesia.

La nueva capilla sacramental fue inaugurada en 1768, interviniendo en su construcción los arquitectos Pedro de Silva y Ambrosio de Figueroa ${ }^{32}$. Con este flamante sagrario y dos estancias contiguas, destinadas a albergar el despachoarchivo parroquial y el baptisterio, se ganaban nuevas y vitales dependencias en el edificio pero, a cambio, fue preciso sacrificar dos de las antiguas capillas que existían en la nave del Evangelio: la de las Ánimas y la de San Pablo, que se hallaban en el tránsito hacia el nuevo sagrario.

Desde mediados del siglo XVI la hermandad de las Ánimas Benditas del Purgatorio ocupaba la capilla inmediata al sagrario. Poco tiempo después, en 1579, apareció una nueva cofradía bajo la advocación de Nuestra Señora de la Encarnación, que ejercía su estación de penitencia en la tarde del martes santo, incluyendo disciplinantes en su procesión. Desde entonces ambas congregaciones compartieron la capilla, con sus respectivos altares, y celebraron sus cultos en este mismo lugar, existiendo evidencias que apuntan a una probable fusión de estas dos cofradías a fines del siglo XVIII, aglutinadas por la devoción al Cristo de la Expiración. Nuevos documentos recientemente localizados demuestran que en esta capilla estuvo el retablo encargado en 1672 por la hermandad de las Ánimas para su imagen titular. Se trataba de un retablo de dos cuerpos, dotado con columnas y una caja u hornacina

${ }^{29}$ APSME., libro 446, s.f.

${ }^{30}$ AGAS., legajo 11580.

31 Ibídem.

${ }^{32}$ HERNÁNDEZ DÍAZ, José, SANCHO CORBACHO, Antonio, COLLANTES DE TERÁN, Francisco: Catálogo Arqueológico..., op. cit., p. 134. 
central, en forma de cruz, destinada a la imagen de un Crucificado ${ }^{33}$. Éste sería, por tanto, el primer altar donde se rindió culto a la impresionante escultura del Cristo de la Expiración, tallada en 1680 por el escultor Pedro Roldán para la cofradía de las Ánimas ${ }^{34}$. A partir de 1768, debido a la comentada desaparición de la capilla, las imágenes que en esta época se veneraban como titulares de la hermandad (Cristo de la Expiración, Jesús de la Misericordia y Nuestra Señora de los Dolores) quedaron instaladas en la nave del Evangelio, en un lugar indeterminado. El inventario de bienes de la parroquia menciona que, en 1783, el Cristo de la Expiración se hallaba en el retablo de San Pablo "de prestado, hasta colocarlo en el lugar que le corresponde"35. Esta situación, incómoda y provisional, que no se consideraba digna ni adecuada por parte de la hermandad, se mantuvo durante varios años más.

Para solucionar este problema, se entablaron conversaciones con los curas de la parroquia y con el patrono de la antigua capilla del sagrario, que ya no pertenecía al linaje de los Mendoza. La hermandad pretendía instalar la imagen del Cristo de la Expiración en el espacio central del antiguo retablo del sagrario, para lo que era preciso retirar el relieve principal, que representaba la Santa Cena. Llegados a un acuerdo en 1790, se aceptó la retirada del medallón de la Santa Cena del retablo y se pensó incorporarlo al nuevo retablo que se iba a construir para la nueva capilla sacramental. Este retablo fue encargado el día 10 de mayo de 1790 al ecijano Francisco Javier Díaz y Acevedo, maestro tallista y arquitecto por la Academia de San Fernando de Madrid, que había presentado su proyecto al Arzobispado de Sevilla poco antes ${ }^{36}$. El diseño del nuevo retablo, de corte clasicista, fue concebido como una gran portada solemne para otro sagrario trasero, más íntimo y recogido, siguiendo la tradición de los sagrarios ecijanos del siglo XVIII. El retablo-portada contemplaba la incorporación en su centro del relieve de la Cena y reaprovechaba otras esculturas existentes en la parroquia. Pese a que no ha llegado a nosotros la traza original y proyecto ideado por Díaz y Acevedo, tenemos la seguridad de que la reutilización del relieve estaba decidida así de antemano, pues entre las observaciones previas hechas a este proyecto por el arquitecto arzobispal José Jiménez, se indica al autor del mismo que "hará subir la clave del medio punto de la fachada para reducir el campo que hase entre el medio punto y el medallón de la Sena"37.

${ }^{33}$ GARCÍA LEÓN, Gerardo, MARTÍN OJEDA, Marina Documentos para la Historia del Arte en Écija..., op. cit.

${ }^{34}$ HERNÁNDEZ DÍAZ, José, SANCHO CORBACHO, Antonio, COLLANTES DE TERÁN, Francisco: Catálogo Arqueológico..., op. cit., p. 294.

35 APSE. (Archivo Parroquial de Santiago de Écija), libro 308, s.f.

36 AGAS., legajo 12340. Cfr. ROS GONZÁLEZ, Francisco. Noticias de escultura. 1781-1800. Sevilla, 1999, pp. 265-270, 862-864.

${ }^{37}$ Ibídem. El nuevo retablo del sagrario ya estaba construido en febrero de 1792, según el informe de Francisco de Acosta, maestro mayor del Arzobispado de Sevilla. Tuvo de coste 15.500 reales, sólo en lo relativo a materiales, talla y ensamblaje. 
Mientras se desarrollaban los trabajos, y antes de que fuera concluido el nuevo retablo se encargaron varios presupuestos para llevar a cabo el dorado y estofado de las pechinas de la cúpula de la capilla, los relieves de los Santos Padres, los ángeles lampadarios, las esculturas de la Fe, la Inmaculada Concepción, Santa Apolonia y otras partes del retablo que se estaba finalizando, entre las que se encontraba el relieve de la Santa Cena que se quería reubicar. Raimundo Espinosa, maestro estofador vecino de Écija, fue uno de los artistas que optaron a realizar este encargo. El presupuesto presentado por dicho artífice incluía la siguiente partida: "Yten para estofar y rascar una medalla de la Sena, que está colocada en el sagrario viejo, con las figuras de a siete quartas, aunque a todas no se le descubre toda su altura, que se hallan estofadas a lo antiguo y, para hacerlo de nuevo, reconose el declarante necesitarse un mil y quinientos reales de vellón"38. Tras analizar varias ofertas, finalmente el contrato del dorado fue adjudicado a Diego Rodríguez, maestro dorador vecino de Sevilla, que se obligó a respetar todas las prescripciones técnicas acordadas. En septiembre de 1792 habían concluido todos los trabajos de dorado del retablo, incluidas las "pinturas de su sentro, como por averlas raspado; por estar aparejadas de mucho tiempo se volvieron a criar de nuevo, aparejándolas para que el dorado quedase permanente" 39 .

En agosto de 1793, cuando el medallón de la Santa Cena ya lucía instalado en el nuevo retablo del sagrario, la hermandad del Cristo de la Expiración solicitó licencia al Arzobispado para instalarse en la antigua capilla del sagrario "y levantar sobre el sitio del antiguo depósito un camarín donde se coloque la ymagen del Santísimo Cristo de la Expiración y ejercer allí las funciones peculiares a esta hermandad"40. Esta petición quedó avalada en el informe remitido a Sevilla por el vicario de Écija en estos términos: "no teniendo dicha hermandad donde colocar la precitada ymagen suplicó a dicho señor patrono le diese permiso y lisensia para poder abrir un arco por el sitio donde se halla la medalla de la Cena de Nuestro Señor Jesucristo y fabricar un nuevo camarín en donde poner dicha sagrada ymagen, dejando el retablo en la perfección que hoy se halla, a costa esta obra de la hermandad"41. En febrero de 1794 se firmó la escritura de acuerdo para la instalación del Cristo de la Expiración en el retablo del antiguo sagrario. En ella se incluían las normas de uso de la capilla por parte de la hermandad, mediante las cuales se reconocían y respetaban los derechos históricos de Francisco Ignacio de Aguilar, Ponce de León, Nava, Ojacastro

38 Ibíd.

39 Ibíd. El contrato del dorado fue suscrito en Sevilla el día 4 de diciembre de 1790. En septiembre de 1792 se pagaron a Diego Rodríguez un total de 17.150 reales por el dorado de las pechinas, santos, relieve central y el nuevo retablo.

40 AGAS., legajo 09923.

41 Ibid. 
y Zaldúa, que por entonces era el patrono de la capilla, como heredero directo del vínculo que fundara su antepasado Juan Martínez de Ojacastro ${ }^{42}$.

A partir de este momento, la hermandad del Cristo de la Expiración quedó establecida en la antigua capilla del sagrario. La falta de espacio suficiente en esta capilla obligó a reubicar en otros lugares de la iglesia al resto de las imágenes titulares de la cofradía. Por esta razón, Nuestra Señora de los Dolores fue instalada en un camarín construido en el retablo colateral del lado de la Epístola, y Nuestro Padre Jesús de la Misericordia, acompañado por la figura arrodillada de San Pedro, pasó a la capilla de los Monteros. El retablo de las Ánimas fue situado en la nave de la Epístola, entre el acceso a la sala de tacas y la capilla de los Monteros.

Durante el siglo XIX se reutilizó el antiguo tabernáculo del retablo del sagrario para albergar una gruta con la Magdalena, que ocultaba la traza gótica original. Según las descripciones del retablo, esta gruta consistía en "una urna con cristal y artísticas puertezuelas con pinturas simulando una cueva, en que aparece la imagen de barro cocido de Santa María Magdalena penintente". Así mismo, en esta época fue adosado un retablo al muro lateral de la antigua capilla sacramental, dedicado a San José y a Nuestra Señora de la Encarnación. Según una descripción fechada en 1849 , se trataba de un retablo "de yeso jaspeado con cuatro columnas de yeso y capiteles de madera dorados"43. Bajo la figura de San José existía una pintura del Santo Rostro, denominada en los inventarios como "el Señor del río" 44.

Con motivo de la restauración general del templo de Santiago, llevada a cabo entre 1966 y 1969 por la Dirección General de Bellas Artes, del Ministerio de Educación Nacional, el retablo de San José fue desmontado y retirado, desconociéndose su paradero actual ${ }^{45}$. Desde entonces la capilla del sagrario recobró la disposición que hoy contemplamos, mucho más cercana a la que pudo tener a mediados del siglo XVI. En el pavimento de la capilla existió, hasta la restauración de los años sesenta, una lápida que cerraba el acceso a la cripta funeraria y que tenía la inscripción: "Esta capilla y bóveda del sagrario viejo de Santiago y el medallón de la Cena del nuevo son de la propiedad del señor Conde del Águila”. Dicho acceso aparece

${ }^{42}$ Ibíd. El compromiso de cesión de la capilla obligaba a la hermandad a costear todos los gastos de apertura del arco y construcción del nuevo camarín, cuidando de no dañar el retablo. También se disponía la reserva de un asiento para el patrono en las solemnidades habituales, la conservación de su blasón familiar, la prohibición de utilizar la cripta de enterramiento y la obligación de mantener encendida una lámpara para la iluminación del retablo.

43 AGAS., legajo 14573-B. Esta información aparece en los inventarios de bienes de la parroquia de 1927 y 1932.

${ }^{44}$ APSE., libro 308, s.f.

${ }^{45}$ MARTÍN PRADAS, Antonio, CARRASCO GÓMEZ, Inmaculada: "Restauración de la iglesia parroquial de Santiago el mayor de Écija. 1965-1969", en Actas de las IX Jornadas de Protección del Patrimonio Histórico de Écija. Écija, 2011, pp. 155-178. 
cubierto hoy con otra lápida moderna de mármol rojo que muestra la leyenda " $\mathrm{Del}$ Águila”.

El retablo sacramental de Santiago ha sufrido otras intervenciones menores a lo largo de sus más de cuatrocientos años de historia, consistentes en la aplicación de repintes y barnices, así como en la reparación y fijación de algunas piezas desprendidas, como la efectuada en 1964 por el tallista y dorador Antonio Hernández. En 1994, junto con el retablo mayor de la parroquia, fue objeto de estudio y diagnóstico de su estado de conservación por parte de la Consejería de Cultura de la Junta de Andalucía. Como consecuencia de ello, el restaurador Juan Carlos Pérez Ferrer elaboró un proyecto integral de restauración que consolidaría su estructura y resolvería todas las patologías que afectaban a la obra. Este proyecto nunca fue ejecutado, probablemente por motivos presupuestarios. No obstante, en él se ponía de manifiesto que los deterioros más preocupantes eran la presencia de xilófagos, algunos problemas en el ensamblaje de las tablas de las pinturas y otras piezas del retablo, la pérdida de materia pictórica, las importantes grietas presentes en varias tablas y, sobre todo, la oxidación y ennegrecimiento general de toda la obra, debido a la aplicación de una cobertura bituminosa superficial, fabricada con una mezcla de barnices, cenizas y tierras, que le fue aplicada en 1961, con la intención de igualar el aspecto general del retablo y de ocultar las pérdidas en las tablas policromadas y en las tallas ${ }^{46}$. Finalmente el retablo ha sido restaurado en 2007 por María Ugarte Monasterio y María del Carmen Suárez Avilés, bajo el patrocinio de la familia Cárdenas Osuna, según demuestra una placa con la siguiente inscripción: "Este retablo del Santísimo Cristo de la Expiración se restauró en el año de 2007 con el mecenazgo de los ilustrísimos señores $D^{a}$ Carmen Jiménez-Alfaro y Salas y don Miguel Ángel de Cárdenas Osuna, condes de Prado Castellano".

Mediante las técnicas actuales de tratamiento de la imagen, y teniendo en cuenta la información y las referencias documentales manejadas a lo largo de este artículo, Julio Ojeda Pérez ha llevado a cabo una hipótesis de restitución ideal, que nos permite imaginar cómo pudo ser el aspecto original del retablo, antes de la reforma de 1792 .

\section{ESTUDIO ARTÍSTICO E ICONOGRÁFICO DEL RETABLO DEL SAGRARIO}

El retablo del sagrario de la parroquia de Santiago de Écija posee la estructura tradicional de los retablos sacramentales tardogóticos, que tanta fortuna gozaron en el reino de Sevilla durante la primera mitad del siglo XVI. Del tipo

46 ADTCCT (Archivo de la Delegación Territorial de las Consejerías de Cultura y Turismo). Caja 1378. Proyecto para la conservación y restauración del Retablo del Cristo de la Expiración, de la Iglesia de Santiago de Écija (Sevilla). 
llamado de batea, consta de dos cuerpos protegidos por guardapolvos y pulseras, y tres calles separadas por pilares compuestos y rematados con agudos pináculos. La calle central aparece sobreelevada y coronada con un Calvario. En su hornacina principal hoy se muestra la escultura del Cristo de la Expiración, sobre un panel liso y dorado que oculta el antiguo camarín, en el lugar donde estuvo originalmente el relieve de la Santa Cena. Con un claro predominio de la decoración pictórica sobre la escultórica, la parte superior del retablo está cobijada por un guardapolvo quebrado, en cuyos tramos horizontales se representan bóvedas de crucería simuladas, con adornos de estrellas, pináculos y finas cresterías caladas.

Los pilares que delimitan las calles se subdividen en baquetones y se decoran con golpes de talla y repisas coronadas con doseletes para pequeñas esculturas de los Padres de la Iglesia, de las que sólo se conservan dos en la actualidad. El verdadero despliegue ornamental del retablo se reserva para los doseles o baldaquinos que coronan las pinturas y, especialmente, para la gran tuba o dosel central que, a modo de chapitel, suele enriquecer con frecuencia los retablos sacramentales del gótico final, señalando a los ojos del espectador la relevancia de la escena representada en el relieve hoy desplazado y, sobre todo, cobija y protege el recinto inferior donde se custodia el Santísimo Sacramento. La tuba de este retablo ecijano es un notable y delicado ejemplo de este tipo de soluciones ornamentales que se compone de tres cuerpos decrecientes, generados a partir de una complicada tracería de arbotantes, formas caladas, tallos vegetales, bulbos y pináculos. Muy vinculada con algunas de las soluciones empleadas en el retablo catedralicio sevillano, se ha llegado a afirmar sobre la tuba del retablo de Écija que "esta superposición de cuerpos y la riqueza ornamental de los mismos, no tiene parangón entre los ejemplos conocidos del área sevillana"47.

Las pinturas del retablo están realizadas al óleo, sobre tablas de madera de pino estucadas. Las calles laterales del primer cuerpo representan a la Virgen de la Antigua y la Visitación. En el segundo cuerpo aparecen Jesús entre los doctores y la Asunción de la Virgen. Las tablas de las pulseras están decoradas con las figuras del emperador Constantino, Santa Elena, Santa Catalina de Alejandría, una Santa no identificada, Santa Lucía, Santa Cecilia, Santa Águeda y San Juan Evangelista. Las puertas del sagrario muestran la Pascua judía y la Cena de Emaús.

Por cuanto se refiere a la arquitectura y talla de la obra, son evidentes las coincidencias entre los recursos ornamentales y estructurales presentes en este retablo y los que hallamos en el mayor de la catedral de Sevilla, por lo que siempre venía siendo atribuido a sus autores o a su círculo más cercano. También se han señalado sus semejanzas con los retablos sacramentales de San Juan de Marchena y de la Colegiata de Osuna.

${ }^{47}$ HERRERA GARCÍA, Francisco: "Los orígenes de una afortunada creación artística. El retablo gótico en Sevilla”..., op. cit., p. 61. 
A la hora de realizar una interpretación iconográfica del conjunto, se ha puesto en evidencia una doble vertiente en la simbología de este retablo: por un lado, el sentido mariano, presente en tres de sus principales pinturas y, por otro, una clara intención eucarística, protagonizada por el relieve de la Santa Cena y las escenas de las puertas del tabernáculo. Más difícil resulta de precisar el espíritu que inspiró al desconocido ideólogo de esta obra al escoger las diferentes devociones que ocupan las pinturas del guardapolvo y pulseras del retablo ${ }^{48}$.

Con respecto al repertorio pictórico, ya en 1950 los autores del Catálogo Arqueológico y Artístico de la provincia de Sevilla vinculaban estas pinturas con la producción de los romanistas flamencos que trabajaban en Sevilla a mediados del siglo XVI, encontrando paralelismos con algunas obras de Hernando de Esturmio y citando la participación de Andrés Morín, en base a la ya mencionada evidencia documental del año 1557, que se conserva en el Archivo de Protocolos Notariales de Sevilla. En cambio, poco después, Diego Angulo atribuía a Campaña la mayor parte de las pinturas. A partir de entonces, todos los historiadores que han estudiado esta pieza la han relacionado con el taller del maestro Pedro de Campaña y con algunos de sus más directos seguidores y colaboradores. Incluso se ha querido ver en las iniciales AGA del libro que aparece como atributo iconográfico de la pintura de Santa Cecilia la posible firma de un hipotético autor. Así mismo, se han puesto de manifiesto las evidentes analogías entre algunas pinturas de esta obra y las que aparecen en los retablos de Santa María de Carmona, Santa Ana de Triana y la Capilla del Mariscal de la catedral sevillana ${ }^{49}$.

En estos momentos, y gracias a la documentación que ahora damos a conocer, podemos confirmar algunas de estas atribuciones y aportar nuevos datos para explicar la génesis de esta importante muestra del patrimonio artístico ecijano. Según demuestra la contabilidad parroquial, el entallador Bartolomé de Ortega construyó el retablo entre 1533 y 1542, cobrando por su trabajo 6.570 reales. Nicolás de León, escultor, cobró 882 reales por llevar a cabo, entre 1539 y 1542, el relieve central de la Santa Cena, las figuras de los Padres de la Iglesia y las del Calvario.

En cuanto a la policromía del retablo, las informaciones que ofrecen las cuentas son más ambiguas e imprecisas y pueden generar dudas a la hora de establecer la autoría del dorado y estofado de las diferentes partes del retablo y, en especial, de las pinturas que cubren una buena parte de su superficie. Las cuentas de fábrica muestran una primera fase de trabajos de pintura y dorado a cargo de los pintores Juan Sánchez y Andrés Morín, entre 1542 y el mes de mayo de 1544, a los que se abonaron 1.762 reales. En febrero de 1545 el visitador del Arzobispado ordenó

48 Ibídem. Debido a su precario estado de conservación, la identificación iconográfica de las pinturas laterales ha planteado a todos los autores que han estudiado el retablo varias dudas y errores, a la hora de reconocer los atributos iconográficos de cada personaje representado.

49 Véase el contenido de la nota 2. 
“que se prosiga la obra del sagrario fasta se acavar" ${ }^{50}$. Pero los nuevos apuntes contables no se reanudan hasta el año 1550, lo que podría hacer pensar en una interrupción de los trabajos del retablo, quizá por motivos económicos (recordemos el pago en especie de trigo que le hace a Morín en ese año), o más bien pudiera deberse a la pérdida o ausencia de las cuentas de fábrica de esos cinco años.

Aunque el escribano que transcribió en 1613 los tres Libros de Visitas donde se anotaban las cuentas de fábrica de la parroquia no lo aclara, ni lo indica expresamente, resulta muy llamativa esta laguna tan importante en unas cuentas que debieron ser muy rigurosas y afinadas, pues se trataba de una empresa de gran importancia para la parroquia, por la envergadura del trabajo y por el altísimo coste económico que suponía para las arcas de la iglesia. Teniendo en cuenta la periodicidad, el rigor y el detalle con que aparecen transcritas todas las partidas de gastos y operaciones relacionadas con la construcción del retablo, durante el periodo comprendido entre junio de 1533 y mayo de 1544, resulta muy extraño que la siguiente anotación de gasto en el retablo se refiera al mes de agosto de 1550 .

Pese a la ausencia de cuentas en estos cinco años, parece lógico que los pagos para la obra del retablo continuaran produciéndose durante ese tiempo y que los trabajos de policromía y pintura se mantuvieran, con mayor o menor intensidad. Si esto fuera así, creemos que entre 1545 y 1550, debieron hacerse otros pagos a Morín y a Campaña, por lo que la mayor parte de las pinturas que hoy contemplamos en el retablo debieron ser realizadas en estos años. Esta posible omisión a la hora de transcribir las cuentas de la obra del retablo podría ser la causa del desfase superior a los mil reales que señalábamos con anterioridad, y que se evidencia entre la cifra aportada por el procurador del Arzobispado en el pleito de 1612 y la que arrojan las partidas contables que han llegado a nosotros. Al mismo tiempo, ello explicaría y podría justificar el exiguo y único pago realizado en agosto de 1550 al pintor Pedro de Campaña, que ascendió sólo a 441 reales. Como ya vimos antes, junto a la partida económica asignada a Campaña aparece rotunda, contundente e incuestionable la frase: "porque pintó el retablo para el sagrario de esta iglesia". El uso del tiempo verbal en pasado induce a pensar que se estaba terminando de pagar al artista el resto de sus honorarios por la realización de una obra que habría sido ejecutada en los años precedentes o que ya estaba concluida, y que lógicamente tuvo que alcanzar un coste muy superior a 441 reales. Pensemos que Pedro de Campaña había cobrado 1.100 reales en 1546 por hacer las nueve pinturas del retablo encargado por María Niño para su capilla privada del convento de Nuestra Señora de la Victoria de Triana, una obra cuyas dimensiones eran prácticamente la mitad de las que tenía el retablo ecijano ${ }^{51}$. El retablo de Triana, hoy perdido, medía 20 palmos

${ }^{50}$ AGAS., legajo 09886, expediente 1, f. 75v.

${ }^{51}$ SANTOS MÁRQUEZ, Antonio Joaquín: Los Ballesteros. Una familia de plateros en la Sevilla del quinientos. Sevilla, 2007, pp. 179 y 187. 
de alto y 12 de ancho $(4,20$ x 2,5 m). El retablo de Écija mide 10,20 x 5,65 m y contiene catorce pinturas.

Los pagos al pintor Andrés Morín continuaron entre agosto de 1550 y septiembre de 1552, periodo durante el que se le entregaron hasta 100 fanegas de trigo a cuenta de su salario, y en el que ya sabemos que terminó cobrando una demasía de 1.140 reales $^{52}$. Una vez ajustadas las cuentas, la cantidad final abonada a Andrés Morín ascendió a 3.634 reales. La importancia de esta elevada cifra queda justificada por el alto valor del oro y los pigmentos utilizados en la policromía del retablo.

Recapitulando, y después de todo lo referido, creemos que existe base documental sólida y suficiente para asignar la autoría de este retablo al maestro entallador Bartolomé de Ortega (1534-1542), hijo y hermano de varios entalladores que realizaron numerosas producciones en la diócesis de Sevilla durante la primera mitad del siglo XVI. Este retablo sacramental de Santiago de Écija se convierte, a partir de ahora, en un claro precedente de otra de las grandes realizaciones llevadas a cabo por Ortega entre 1557 y 1560, el retablo de San Juan Bautista de Marchena, cuya parte escultórica correspondió a Roque de Balduque ${ }^{53}$.

Igualmente, queda demostrada la ejecución de las esculturas y del relieve central a cargo del escultor Nicolás de León (1539-1542). Este artista había tallado poco antes doce figuras de santas mártires para las capillas de los alabastros de la catedral de Sevilla -por las que cobró 814 reales-, varios capiteles y un escudo para el Ayuntamiento de esa ciudad, así como otros retablos para el convento dominico de Jerez de la Frontera y para el conde de Ureña ${ }^{54}$.

Dadas las evidentes diferencias en cuanto a calidad y estilo que muestran las pinturas, así como las analogías comentadas con los retablos de Carmona, Triana y la catedral sevillana, quedaría por dilucidar el grado de participación de la mano del maestro Pedro de Campaña en la ejecución del repertorio pictórico del retablo, así como el alcance de los trabajos llevados a cabo por su taller y por Andrés Morín. Recordemos que Campaña y Morín se obligaban a pintar y dorar el retablo de

${ }^{52}$ Equivalentes a 38.758 maravedís. Véase nota 19.

53 PALOMERO PÁRAMO, Jesús: El retablo sevillano del renacimiento. Análisis y evolución. Sevilla, 1983, p. 122. RAVÉ PRIETO, Juan Luis: Arte religioso en Marchena. Siglos XV-XIX. Marchena, 1986, pp. 22-23. HERRERA GARCÍA, Francisco: "Los orígenes de una afortunada creación artística. El retablo gótico en Sevilla”..., op. cit., pp. 60-61.

${ }^{54}$ HERNÁNDEZ DÍAZ, José: "Nicolás de León, entallador". Archivo Español de Arte, $\mathrm{n}^{\circ}$ XI, 1935, pp. 247-256. MORALES MARTÍNEZ, Alfredo: "Puntualizaciones sobre la obra escultórica de Nicolás de León". Boletín del Instituto y Museo Camón Aznar, tomo XXV, 1986, pp. 17-22. MORALES MARTÍNEZ, Alfredo. "La arquitectura en los siglos XVI, XVII y XVIII”, La Catedral de Sevilla. Sevilla, 1991, p. 181. ROMERO BEJARANO, Manuel: "El escultor Nicolás de León en Jerez, I, II y III". Diario de Jerez, 10, 25 y 31-marzo-2013. 
Santa Ana de Triana en 1557, en compañía de Andrés Ramírez, Antón Pérez, Antón Sánchez y Pedro Jiménez ${ }^{55}$.

Como ya destacó Juan Miguel Serrera en 1989, debemos tener en cuenta que Campaña pintaba al dictado de la clientela para la que trabajaba y que las diferencias estilísticas, a veces, podían estar motivadas por los diversos niveles de exigencia que se le imponían o, incluso, por el lugar para el que estaban destinadas las pinturas. Por estas razones, "resulta comprensible que Campaña no cuidara de igual forma la ejecución de una tabla destinada a figurar en el banco de un retablo que se exhibiría en la catedral de Sevilla, que la de otra que se insertaría en el registro superior de un retablo pintado para una de las parroquias de Écija" ${ }^{56}$.

Con independencia de los numerosos repintes, lagunas y barridos de materia pictórica que hoy muestran las tablas del retablo - que han degradado notablemente su estado de conservación-, destacaremos por su calidad y cercanía a la obra de Campaña las cuatro pinturas principales de gran formato que flanqueaban el relieve de la Santa Cena, las que decoran las puertas del sagrario, así como las que representan a San Juan Evangelista, Santa Águeda y Santa Cecilia. El resto de pinturas muestran una factura desigual, y en ellas se hace más evidente la intervención de los colaboradores de Campaña.

A modo de conclusión, creemos que, con esta aportación documental se proporcionan datos decisivos para establecer la cronología general y la autoría de una pieza clave de la retablística conservada en Écija y se ofrecen nuevos aspectos para avanzar en la investigación y el conocimiento del rico panorama artístico sevillano de la primera mitad del siglo XVI.

Fecha de recepción: 10 de julio de 2015.

Fecha de aceptación: 20 de noviembre de 2015.

${ }^{55}$ HERNÁNDEZ DÍAZ, José: Arte hispalense de los siglos XV y XVI. Documentos para la Historia del Arte en Andalucía, T. IX., Sevilla, 1937, pp. 31-33.

${ }^{56}$ SERRERA, Juan Miguel: "Pedro de Campaña: obra dispersa” ..., op. cit., p. 9. 


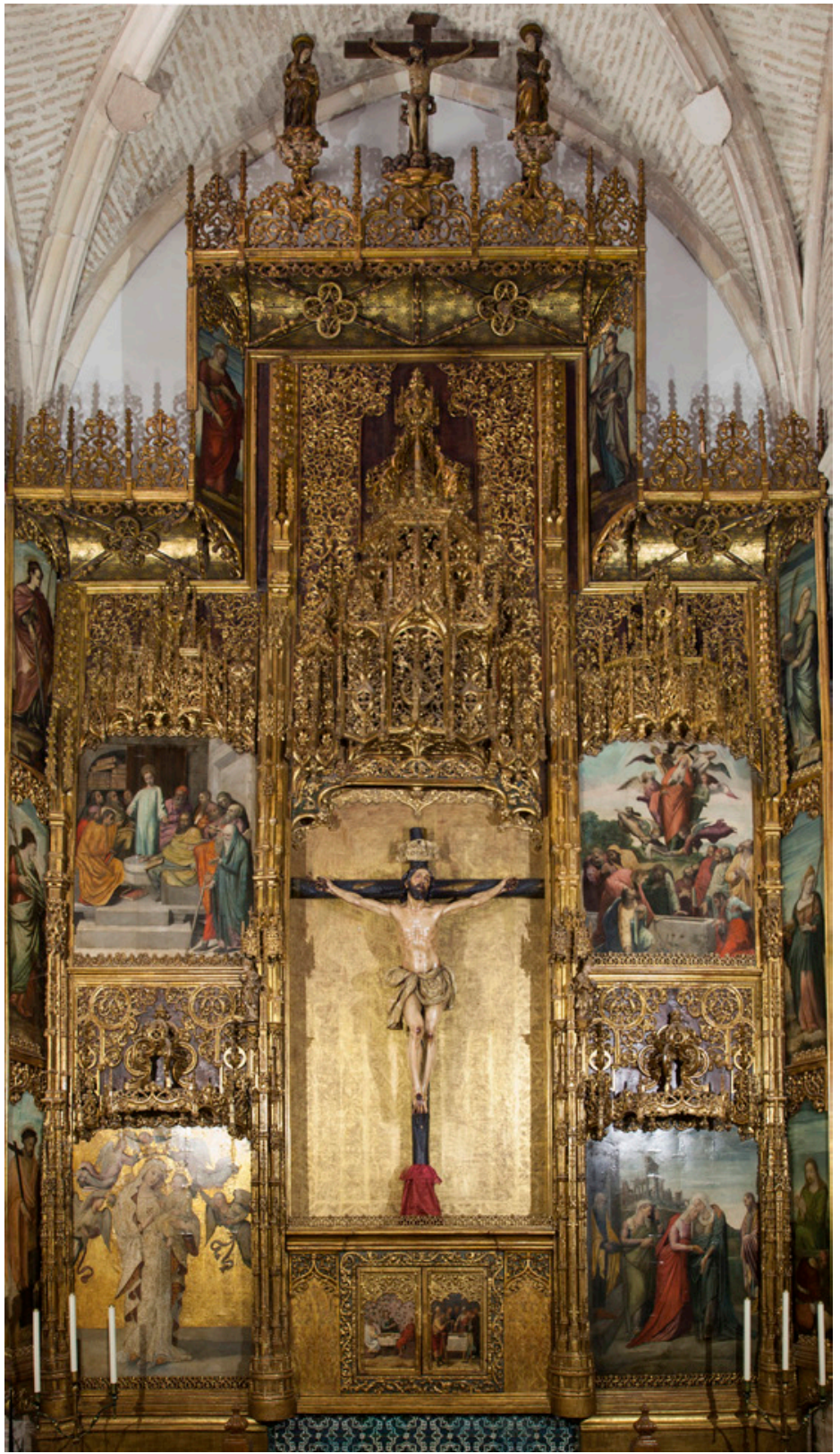

Figura 1. Retablo sacramental. Bartolomé de Ortega, Nicolás de León, Juan Sánchez, Andrés Morín y Pedro de Campaña. 1533-1552 (foto Julio Ojeda Pérez).

LABORATORIO DE ARTE 28 (2016), pp. 77-102, ISSN 1130-5762

e-ISSN 2253-8305 - DOI http://dx.doi.org/10.12795/LA.2006.i.01.04 


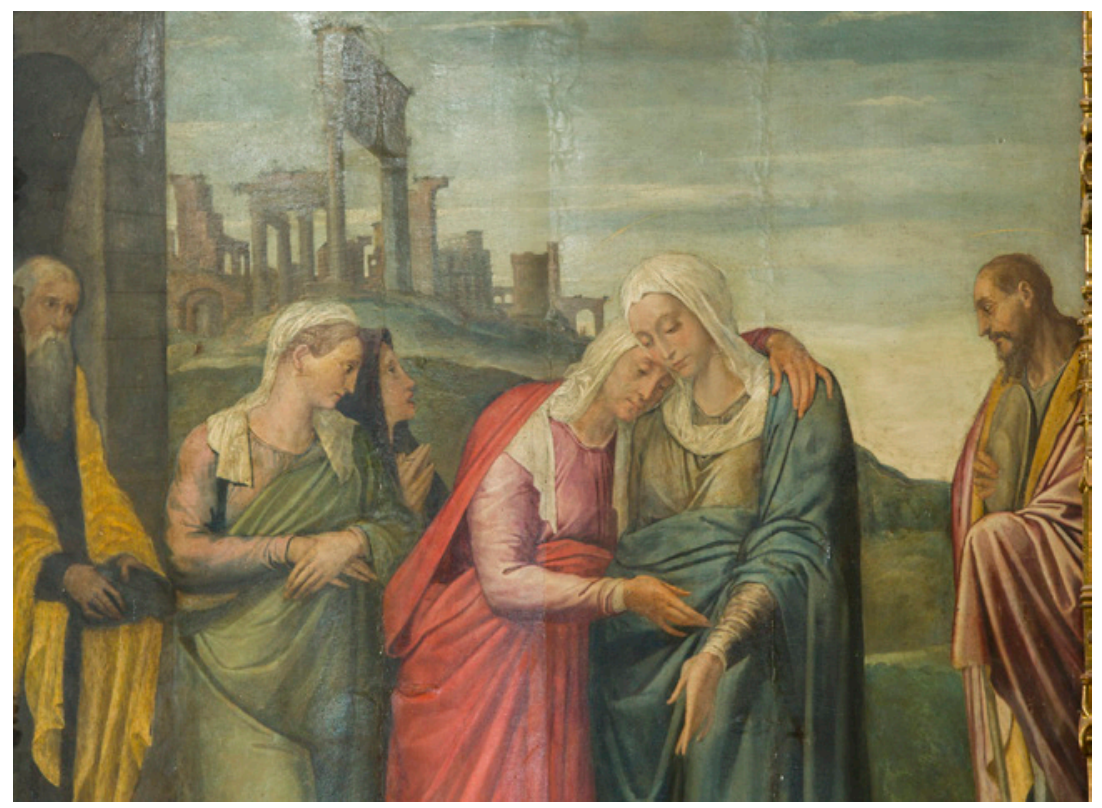

Figura 2. Visitación (detalle). Pedro de Campaña. 1545-1550 (foto Julio Ojeda Pérez).

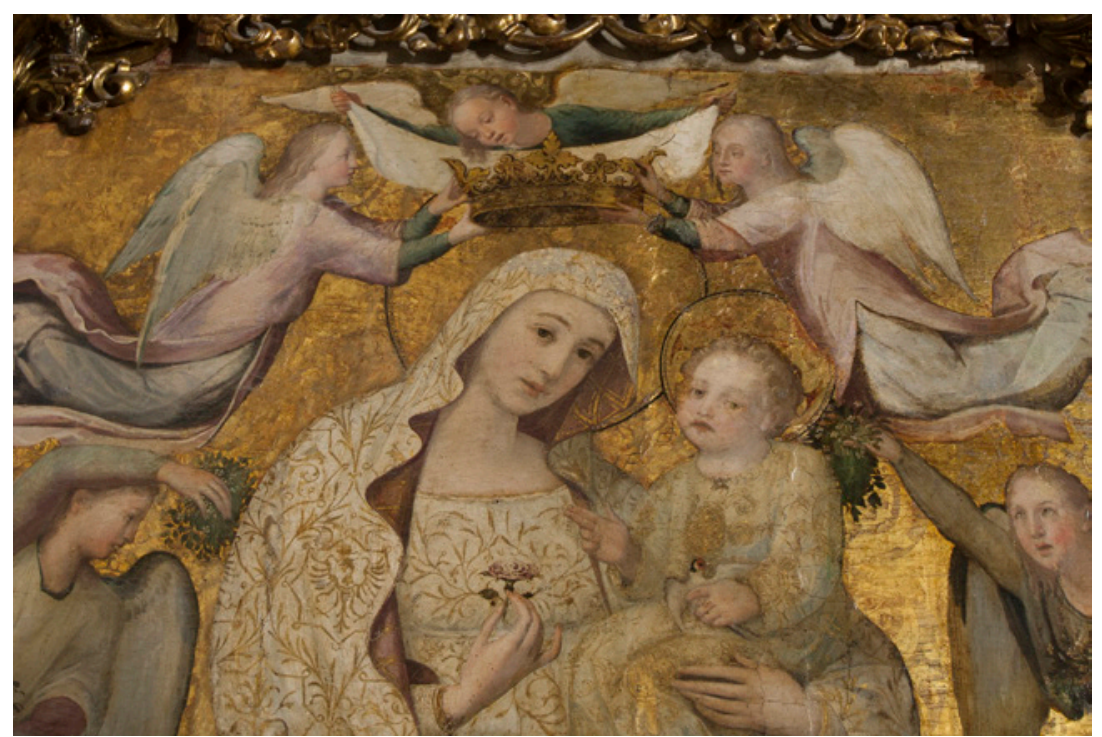

Figura 3. Virgen de la Antigua (detalle). Pedro de Campaña. 1545-1550 (foto Julio Ojeda Pérez). 


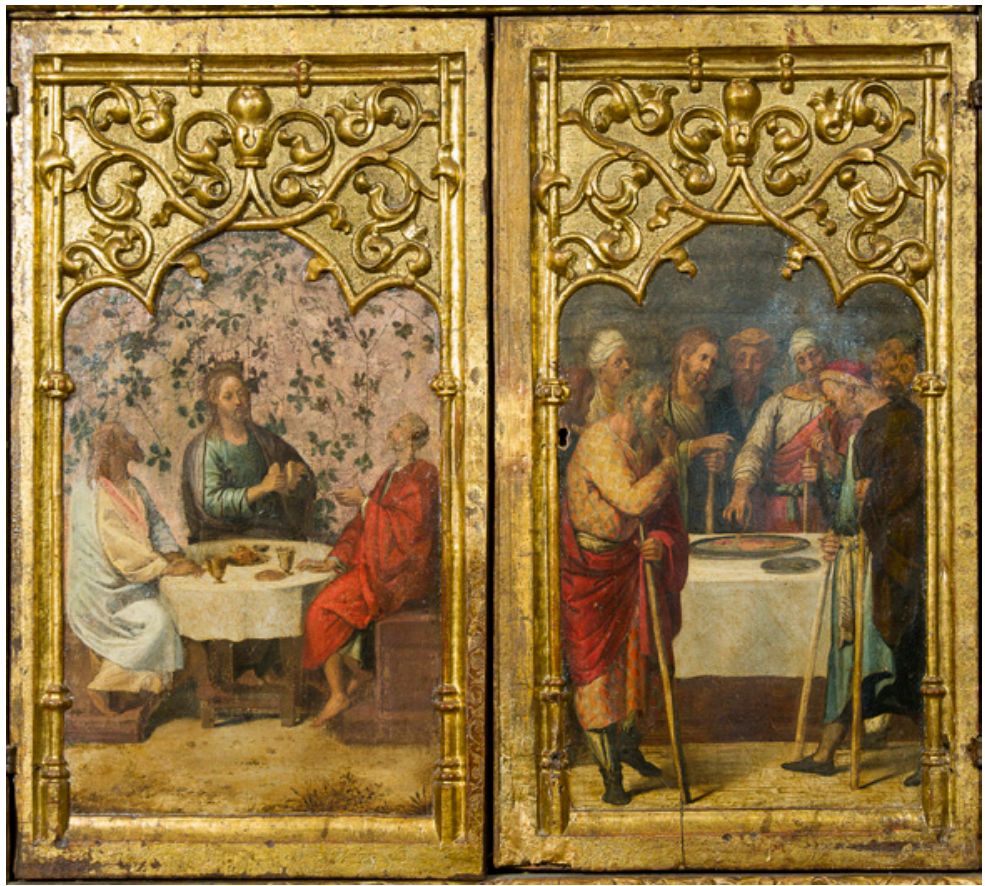

Figura 4. Pascua judía y Cena de Emaús. Pedro de Campaña. 1545-1550 (foto Julio Ojeda Pérez).

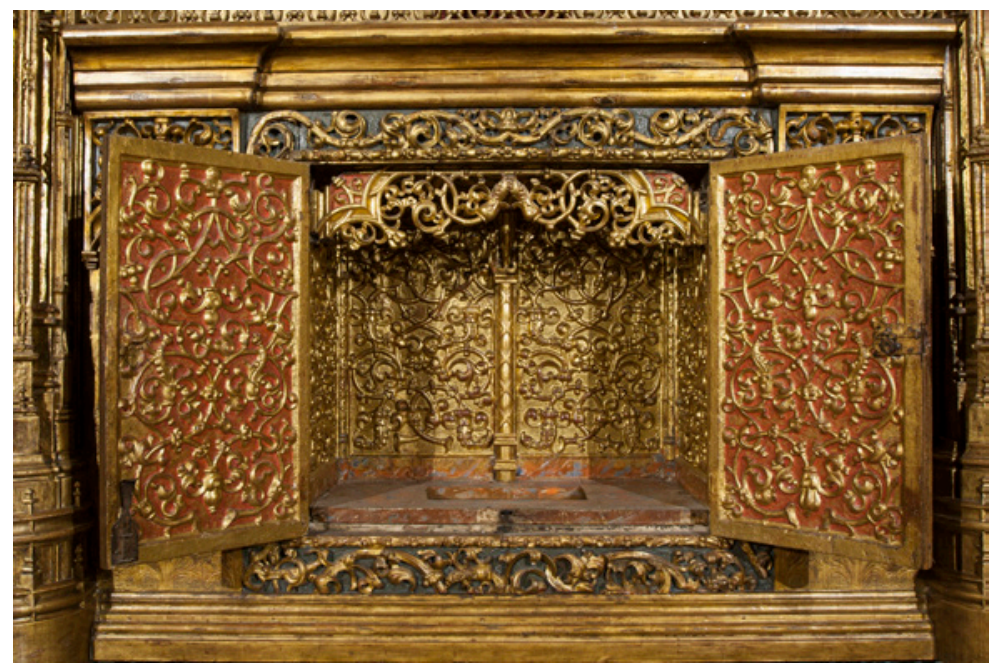

Figura 5. Interior del sagrario. Bartolomé de Ortega. 1533-1542 (foto Julio Ojeda Pérez). 


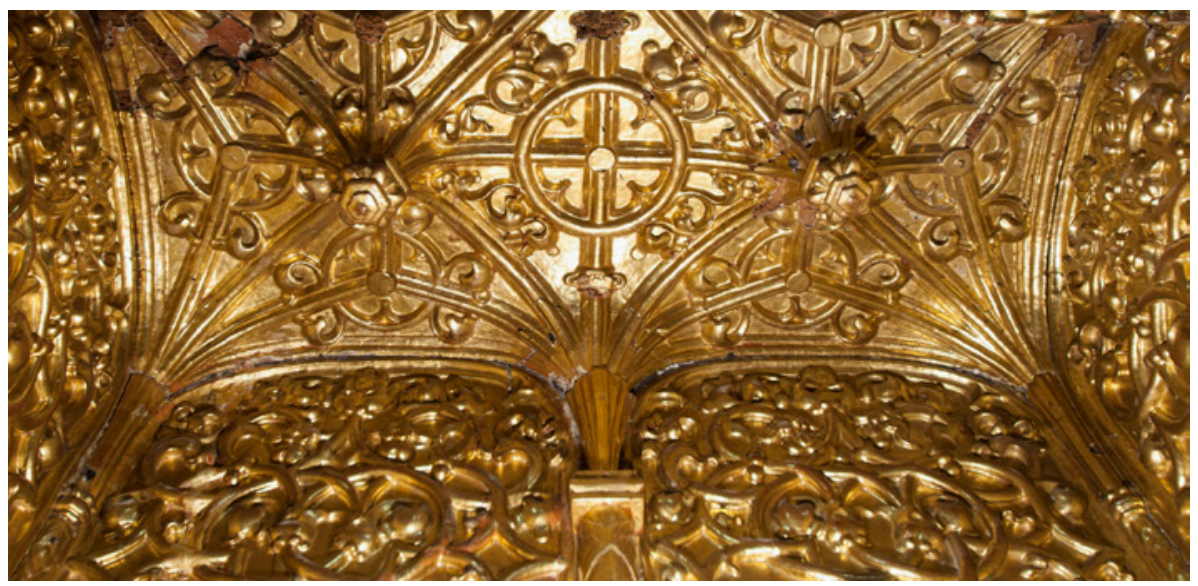

Figura 6. Interior del sagrario. Bartolomé de Ortega. 1533-1542 (foto Julio Ojeda Pérez).

Figura 7. Crucificado. Nicolás de León. 1539-1542

(foto Julio Ojeda Pérez).

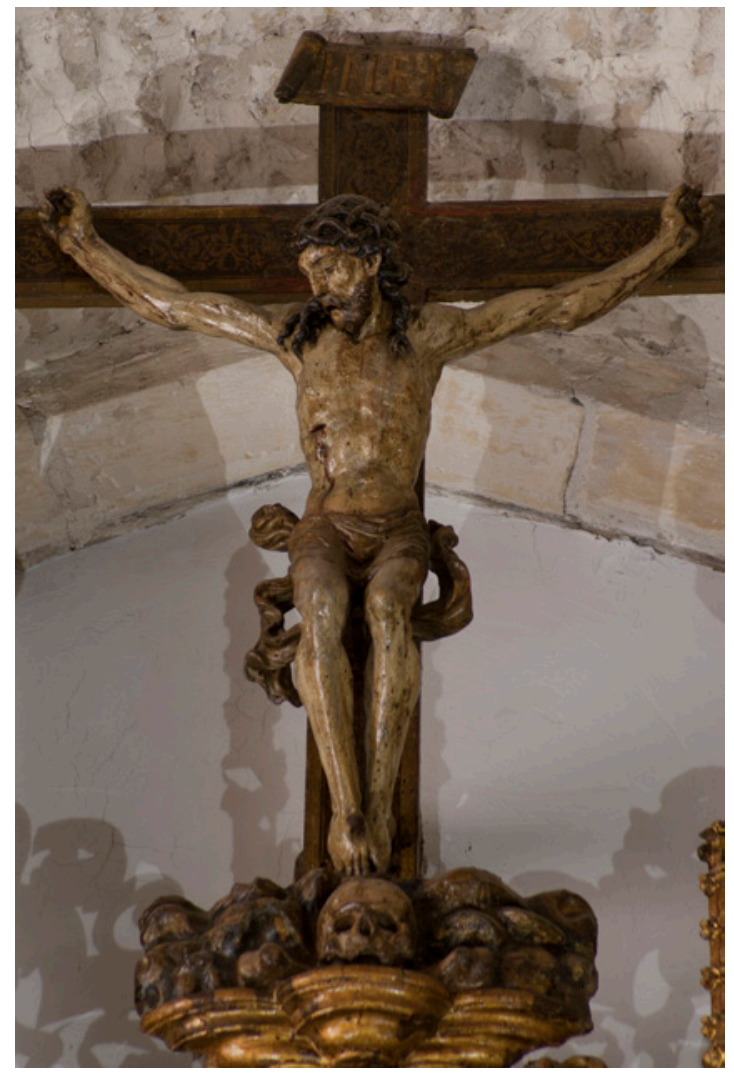

LABORATORIO DE ARTE 28 (2016), pp. 77-102, ISSN 1130-5762 e-ISSN 2253-8305 - DOI http://dx.doi.org/10.12795/LA.2006.i.01.04 

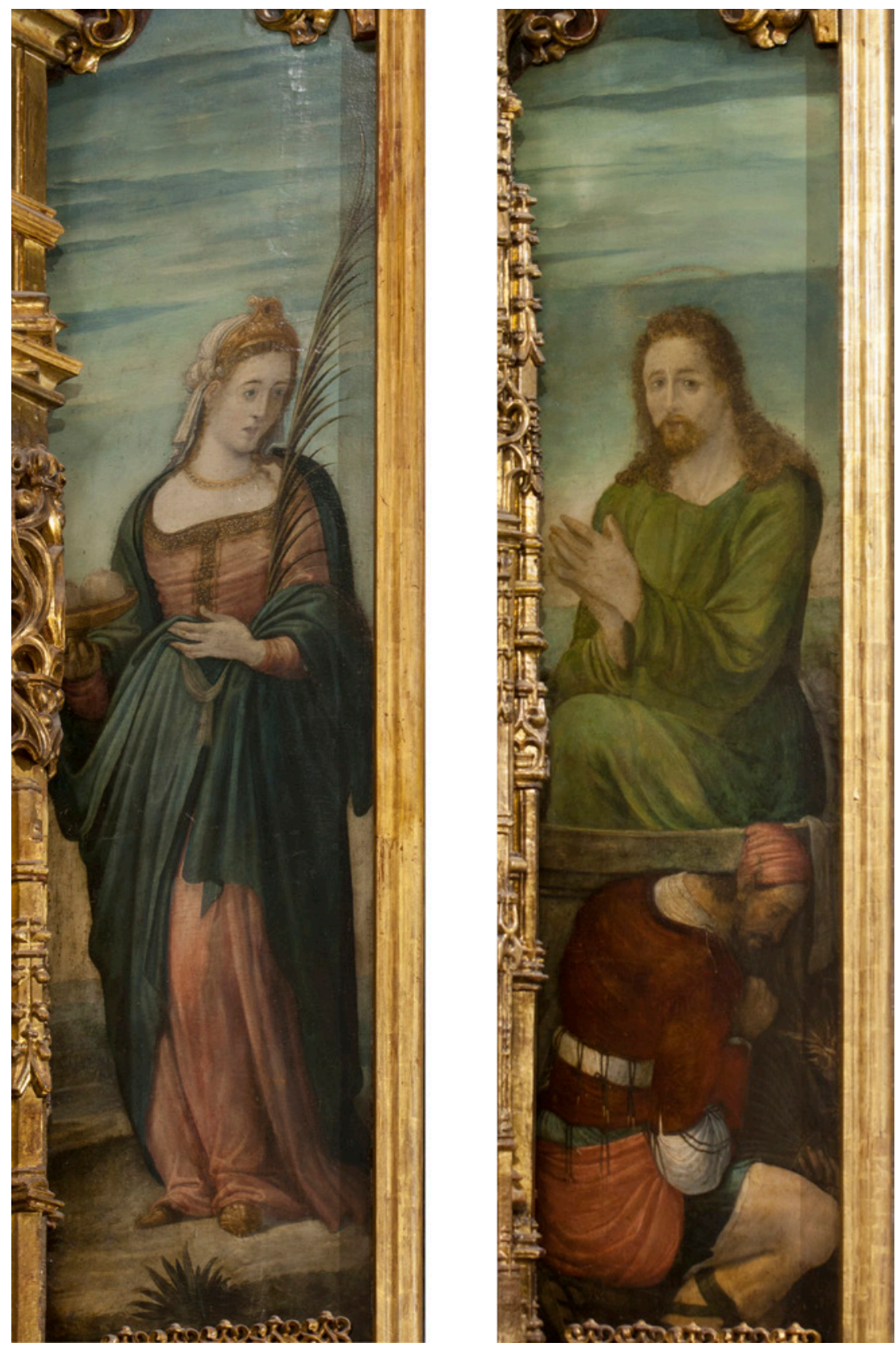

Figura 8. Santa Águeda y San Juan Evangelista. Pedro de Campaña. 1545-1550 (foto Julio Ojeda Pérez). 


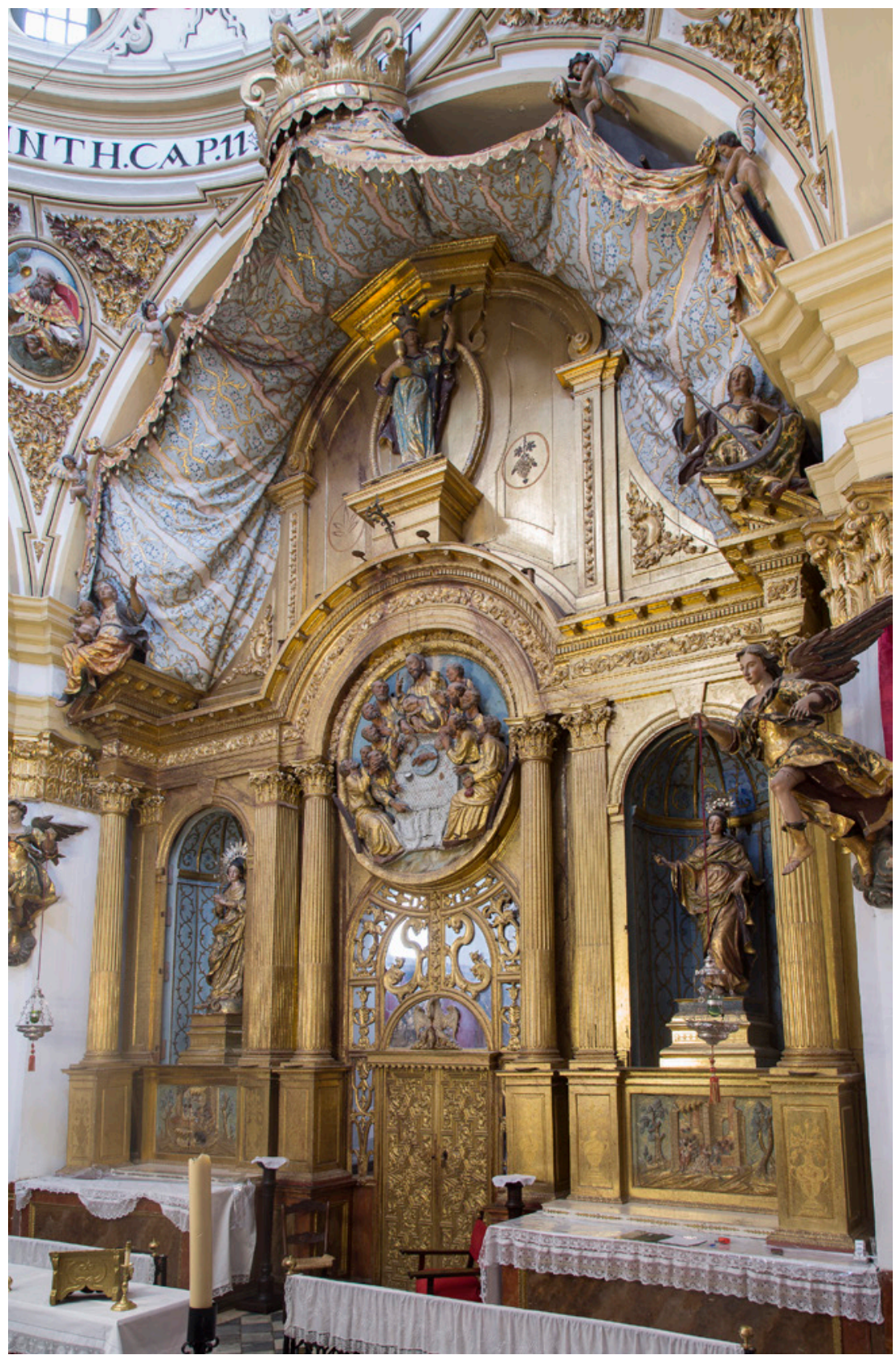

Figura 9. Retablo sacramental. Francisco Javier Díaz de Acevedo. 1792 (foto Julio Ojeda Pérez) 


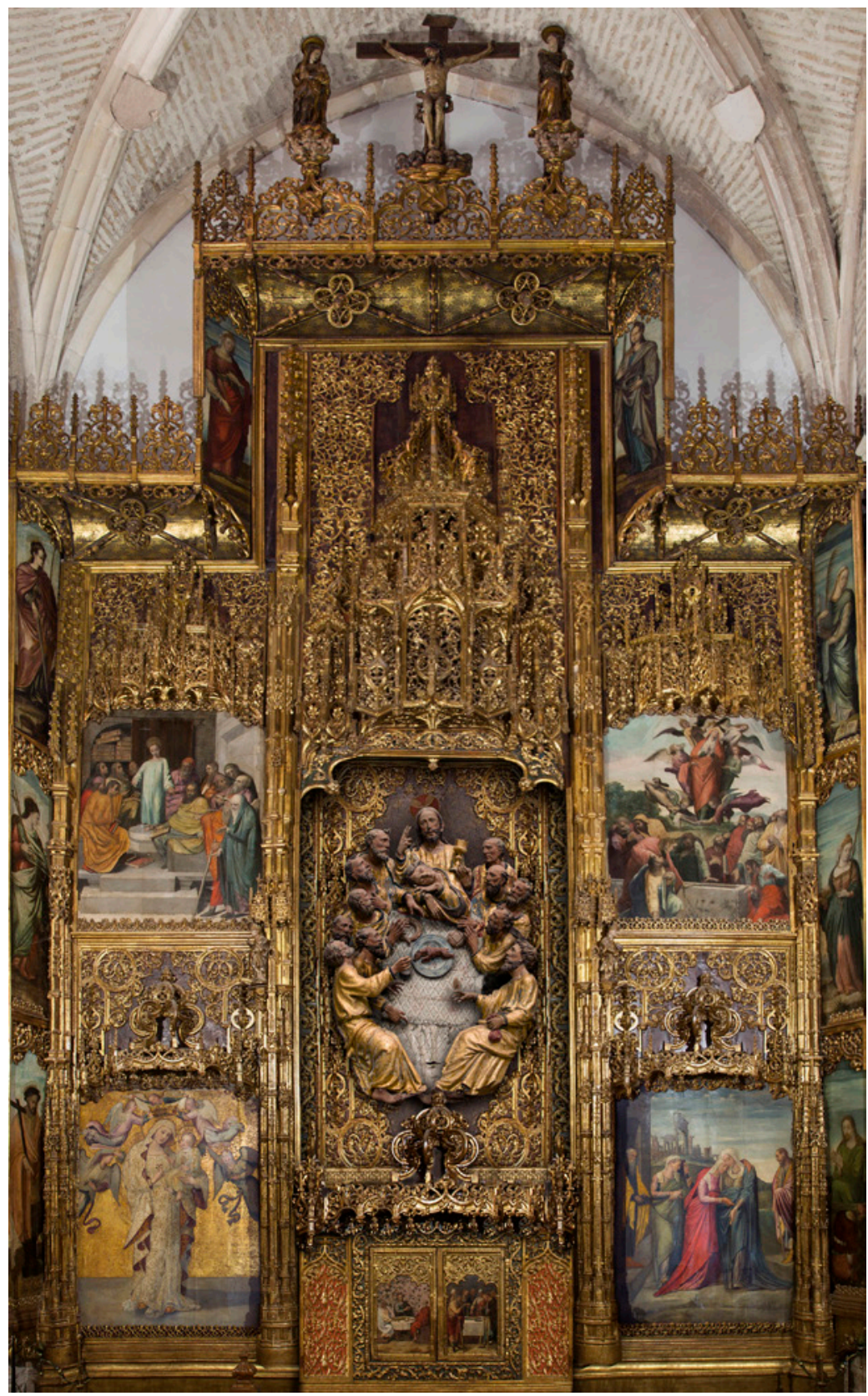

Figura 10. Retablo sacramental. Hipótesis de restitución realizada por Julio Ojeda Pérez. 2015.

LABORATORIO DE ARTE 28 (2016), pp. 77-102, ISSN 1130-5762

e-ISSN 2253-8305 - DOI http://dx.doi.org/10.12795/LA.2006.i.01.04 